\title{
Koers - reflections on the origin and highs and lows of a focussed academic journal
}

\author{
Author: \\ Annette L. Combrink ${ }^{1}$ \\ Affiliation: \\ ${ }^{1}$ Faculty of Theology, \\ Potchefstroom Campus, \\ North-West University, \\ South Africa \\ Correspondence to: \\ Annette Combrink \\ Email: \\ annette.combrink@nwu. \\ ac.za \\ Postal address: \\ Private Bag X6001 \\ Potchefstroom 2520, \\ South Africa \\ Dates: \\ Received: 07 Oct. 2012 \\ Accepted: 08 Oct. 2012 \\ Published: 13 Dec. 2012 \\ How to cite this article: \\ Combrink, A.L., 2012, 'Koers \\ - reflections on the origin \\ and highs and lows of a \\ focussed academic journal', \\ Koers - Bulletin for Christian \\ Scholarship 77(1), Art. \#434, \\ 2 pages. http://dx.doi.org/ \\ 10.4102/koers.v77i1.434
}

C 2012. The Authors. Licensee: AOSIS OpenJournals. This work is licensed under the Creative Commons Attribution License.

\section{Introduction}

Koers strives to promote foundational reflection in science. This includes contemplation of the philosophical presuppositions of scientific disciplines, as well as reflection on the role of worldview in science. The official body is the Koers association, which has been in existence since 1926. Koers: Bulletin for Christian Scholarship is the association's interdisciplinary and peer-reviewed journal which has appeared quarterly since 1935. (Koers 2012)

Not quite accurate in all respects, but this is one of the results that appears, when one uses the search engine Google, to define Koers.

Koers has been synonymous with the Potchefstroom University for Christian Higher Education (CHE) over a long period. Since its inception it has tracked the University and its history, and has provided an outlet for authors to voice their ideas and convictions about Christian scholarship and its role within the wider context of faith and scholarship. Its existence has not been without problems and threats and those members of the Koers Association and of the editorial board and more latterly the publications office have worked hard to ensure that the journal could go on existing in a way that would be a credit to the underlying ethos and philosophy, whilst also maintaining the highest academic standards.

\section{The early history}

In July 1928 the first edition appeared of a journal called Die Wagtoring. The journal, it is said, was the response to a long history of waiting for a journal amongst Calvinist-minded people who wanted to publish in and read such a journal. It was said that the journal would be mainly theological in focus, but that it would also from time to time publish articles in other disciplines. In June 1933 the journal made an announcement in print to the effect that it had been reorganised into a new journal, with a new board of directors and an editorial board. It was hoped that the subscribers to the previous journal would remain subscribers of the new journal. There had clearly been a lot of thought behind the change, and a firm focus was decided on, viz. that contributions would have to be 'In thy light' ${ }^{1}$, thus the avowed purpose of the journal was to take Christian scholarship forward. An important decision was that the journal would not be a semi-official publication of the University, but that it would be governed by a board of directors and an editorial board, hence retaining its independence (a decision which would have important ramifications for the journal in time to come). The first edition of Koers was published in August 1933 (according to Die Veteraan, the alumni journal of the University). An important decision in the early days had been that the journal should publish 50\% academic content and 50\% popularscientific content in order to attract a larger readership and make the 'message' of Christian scholarship more widely accessible and available to the readership.

The Koers Assocation became the governing body of the journal, intended to provide independence from the University and to provide guidance to the journal and ensure that the focus of the journal remained uncompromisingly clear. This has been the focus of the association throughout its long history.

\section{Troubled waters and financial vicissitudes}

In the late 1970s a special plea was made to the University that the University Council should, in view of the special bond between Koers and the University, subsidise the journal in a far more substantial manner, seeing that the journal was not only in financial need but also needed as a matter of great urgency to be supported logistically - by way of an office, support staff and a budget that would make the journal more viable and maintain the important role that it played within the community of Christian scholars not only in South Africa but in a much wider context,

1.These words from Psalm 36 were the motto of the University, inscribed on the crest of the University for many decades, until the merger of the Potchefstroom University with the University of the North-West in Mafikeng to become the North-West University, and without the 'surname' of the University, which had long carried the essence of the 'for Christian Higher Education' that set the Potchefstroom University apart from other universities in the country. 
and witness also from the outside editorial associates of the journal. After some consideration, and requirements to provide more information, the Council of the University decided to make a more substantial contribution and the journal could literally breathe again. This matter was picked up again in the course of the eighties, as requirements for journals became more stringent in view of the impending system of journal accreditation which has been closely linked to the far stronger, indeed in some senses draconian requirements for an increase in the number of academic publications across all the tertiary institutions in the country.

The earlier hand-to-mouth existence had to be reconsidered (at some stage in the seventies and early eighties, the Koers 'editorial office' was carried around in a bag and boxes by a part-time editorial assistant. This was clearly not viable for a journal that had begun to attain real academic respectability and had to comply with the requirements of proper refereeing and record-keeping). The upshot was that a publications office was in the course of time established at the University, with the office hosting other journals as well - In die Skriflig, Literator and Koers (all of which subsequently became accredited, Koers first of all, and therefore subsidybearing) as well as the opinion paper, Woord en Daad, which did not generate subsidy income, but which was considered important enough to be kept on board and subsidised to a large extent by the other journals. The funding formula changed considerably, as the journals now had a different form of revenue, viz. page fees payable by authors and the University benefited significantly in terms of subsidy for publications by staff members in these journals.

Because of early requirements that the journals, as the formal mouthpieces of academic associations, should remain independent of any one academic institution, the publications office, although situated on the Potchefstroom Campus, retained an independence reflected in the fact that the staff members were contracted and employed by the Koers Association, which had, for this purpose, to register as an employer. This had the advantage that independence could be demonstrated, but had the disadvantage that the employment status of the staff remained that of annually contracted workers with no benefits. This has also now been rectified in view of the fact that accreditation requirement has to some extent been relaxed. The publications office has over time developed an enviable reputation for efficiency and professionalism.

\section{Highlights}

Since its inception as Koers in 1933 the journal had maintained its identity and its solidity as an academic mouthpiece, and even during the war years the publication went on, with regular features in Die Veteraan to commemorate small milestones such as the eighth birthday and so forth.

In April 1953 Koers was dedicated to Prof. J. Chris Coetzee on his 60th birthday. Special mention was made of the fact that he had for many years been a member of the Board of Directors, and had made a substantial contribution to the development of the journal. The following year, when
Koers came of age, Prof. Coetzee resigned from the Board of Directors. The editorial board over time contained the names of illustrious academics - in this instance the editor was Prof. H.G. Stoker, and he was supported by Prof. S. du Toit, Prof. H. Venter and Prof. J.H. Coetzee, as adviser.

The year 1984 saw the celebration of the first 50 years of Koers. The event took place on the Campus and the speakers included Prof. P.G. Snyman, Mr B.J. du Toit, Mr G.J. Kahl, Dr Jan van der Linde and Prof. P.G.W. du Plessis, as well as Dr A.L. Combrink and Prof. P.G. Schoeman of the Free State.

And now, in 2011, a belated celebration of 75 years of Koers - at this stage a journal with a good standing, with a good academic reputation, and supported through the very able publications office. It is also of course in the nature of things inevitable that thing should change, and Koers will also be donning a new electronic jacket to be in step with the times and to be even more readily accessible to a new generation of academic readers.

\section{Reputation}

Some academics who built part of their academic reputation on Koers should be named. One such was Totius, Dr J.D. $\mathrm{du}$ Toit, who played such a signally important role in the history of the University and was instrumental in bringing the University to Potchefstroom in the first place when a decision had to be taken about the fate of the University that had originated in Burgersdorp as a theological seminary after the devastation of the Anglo-Boer War.

Another very important author was L.J. du Plessis philosopher and political scientist, who used Koers extensively to publish his ideas. His oeuvre was never published in a very organised manner, but an analysis of his political and philosophical ideas as they pertained to his views of Afrikanerdom and Calvinism is provided in the dissertation by Prof. Pieter Potgieter, himself a former editor of Koers. L.J. du Plessis, for example, was wholly opposed to the notion of discrimination in his views of what constituted a nation and nationhood, and his rather fraught relationship with the establishment was partly played out in the pages of Koers. A statement such as the following (in 1960) typified his stance: 'Hy het tereg blanke baasskap aangewys as die grond van Suid-Afrika se wêreldverstotenheid'.

And Prof. Johan van der Vyver also published extensively in Koers, giving expression to thought-provoking and at times strongly-voiced opinions, as did Prof. Bennie van der Walt, who has been one of the most prolific contributors to the journal that started humbly, but that has now achieved a respected place in the galaxy of scientific journals in South Africa, with a secure niche in the world in the field of focussed journals - in this instance, with a focus on the Christian worldview in a way that is non-exclusive, but uncompromising.

\section{References}

Koers, n.d., Home, viewed from http://www.koers.co.za 